\title{
Eliza Khemissi
}

Adam Mickiewicz University in Poznań

e-mail: algorytm@amu.edu.pl

\section{PROBLEMS OF MONOTONICITY \\ OF SOME POPULAR RISK MEASURES}

\section{PROBLEMY MONOTONICZNOŚCI PEWNYCH POPULARNYCH MIAR RYZYKA}

DOI: $10.15611 /$ ekt.2016.2.08

Summary: In the article the author checked the properties of coherent measures of risk for Expected Value, Expected Shortfall, Maximum Loss (for losses weighted with probability), Median, Median Absolute Deviation, "Arithmetic Mean of Absolute Deviations from Median", Quantiles, Cumulative Distribution Function and Mid-Range in connection with the last financial crisis. Methodology of the research - mathematical proving and theoretical analysis. Results. The survey shows that the above functions are not coherent measures of risk with some definition of stochastic order and in many cases not measures of risk in terms of the axiomatic definition. The paper shows also that the lemma used in the literature to prove monotonicity of Expected Shortfall is not truth and we will prove the lemma with the opposite relation. Value of the paper - Mathematical proofs in the field of risk measurement. Showing some problems with monotonicity of risk measures. Contradicting the lemma of monotonicity of Expected Shortfall. Own definition of first degree stochastic order.

Keywords: measures of risk, Expected Shortfall, Expected Value, Maximum Loss, coherence.

Streszczenie: W artykule autorka sprawdziła właściwości koherentnych miar ryzyka dla wartości oczekiwanej, oczekiwanego niedoboru, maksymalnej straty (dla straty ważonej prawdopodobieństwem), mediany, absolutnego odchylenia medianowego, ,średniej arytmetycznej odchyleń bezwzględnych od wartości średniej”, kwantyla, skumulowanej dystrybuanty i średniego rozstępu - w związku z ostatnim kryzysem finansowym. Przyjętą metodologią badań było matematyczne dowodzenie i analiza teoretyczna. Badanie pokazało, że powyższe funkcje nie są koherentnymi miarami ryzyka z niektórych definicji porządku stochastycznego oraz w wielu przypadkach nie są miarami ryzyka w kategoriach definicji aksjomatycznej. Pokazano również, że lemat stosowany w literaturze do udowodnienia monotoniczności oczekiwanego niedoboru nie jest prawdziwy, jest inaczej jedynie z przeciwnym znakiem nierówności. Wartość dodaną pracy stanowią: matematyczne dowody w zakresie pomiaru ryzyka, pewne problemy dotyczące monotoniczności miary ryzyka, zmieniony lemat o monotoniczności miary ryzyka, a także własna definicja porządku stochastycznego pierwszego rzędu.

Słowa kluczowe: miary ryzyka, oczekiwany niedobór, wartość oczekiwana, maksymalna strata, miary koherentne. 


\section{Introduction}

Risk measurement is an important issue in economics and especially in finance. The role of risk management in the economy is increasing especially since in 2007-2009 there occurred an important financial crisis connected with irresponsible financial risk management [Ferguson 2010]. We understand the necessity of risk analysis which may be conducted with the application of risk measures. The process of risk management may be defined as decision making and actions realization which lead to the achievement of an acceptable level of risk (see [Jajuga 2007]). The need of risk measuring came into existence in the 1990s when many bankruptcies took place on the world financial markets. One of the most important and well-known was the bankruptcy of the English Barings Bank in 1995. [Staniec, Zawiła-Niedźwiedzki 2008]. Risk measurement is one of the few stages in the risk management process based on qualitative methods and statistical and mathematical functions. In this article the author will recall the unconditional functions of volatility and the measures based on quantile of statistical distribution. She will try to prove that Expected Value, Expected Shorftall, Median, Maximum Loss (with losses weighted with probability), Median Absolute Deviation, Arithmetic Mean of "Absolute Deviations from Median", Quantiles, Cumulative Distribution Function and Mid-Range, fulfill the axioms of coherent risk measure of Artzner et al. (see [Uniejewski 2004; Buszkowska 2015]). Furthermore the author will justify that the important lemma, applied in the paper of Uniejewski (see [Uniejewski 2004]), used in the proof of monotonicity of Expected Shortfall, is good in its opposite form and she will prove the opposite theorem to the lemma.

\section{Basic theorems and definitions}

Expected Shortfall - (see two papers [Trzpiot 2008; Acerbi, Tasche 2002]), may be interpreted as the mean of the worst $(1-\alpha) \%$ loss cases on condition that these losses are bigger than Value of Risk.

Now we will present and comment on the definition of measure of Risk

\section{Definition (Measure of Risk)}

Measure of risk is a function which maps the elements of some linear subspace $V$ of some space of random variables specified on the random space $(R, F, P)$, which contains the constants in a set of real variables space

$$
\rho: V \rightarrow R \text {. }
$$

It fulfills the following axioms:

1) monotonicity:

for every $X, Y \in V$, if $X \leq Y$ then, $\rho(X) \leq \rho(Y)$. 
This implication may denote that smaller capital is combined with smaller risk in negative understanding of a risk.

2) invariance: for every $a \in R$ and every $X \in V$

$$
\rho(X+a)=\rho(X)-a .
$$

The second axiom may be interpreted such that when we add some money to the portfolio, the risk connected with this portfolio falls if the risk is defined neutrally as a possible profit from owning this portfolio. This definition does not include the interest rate from the paper of Artzner et. al. [1998], but is similar to the definition: $\rho(X+a)=\rho(X)+a$ [Artzner et al. 1997; Trzpiot 2008]. In this case, risk should be interpreted as a possible profit, so it is positive. Since the values taken by measures of risk are real, we can easily order and compare the risk variables in respect of the quantity of risk. A measure of risk is coherent when it fulfils conditions:

1) positive homogenousness

For every $\lambda \geq 0$ and for every $X \in V$. it occurs $\rho(\lambda X)=\lambda \rho(X)$.

This axiom may denote that the multiplication of the invested wherewithal makes risk increase proportionally, for example when we analyze catastrophes or playing on a stock market.

2) subadditivity: for every $X, Y \in Y$ there is a relation

$$
\rho(X+Y) \leq \rho(X)+\rho(Y) .
$$

In a well diversified portfolio, risk of total loss of the portfolio is not bigger than the risk of the loss of its individual components. The well- known example of no coherent measure is Value at Risk. The famous example of coherent measure of risk according to the literature is Expected Shortfall. The conditions of coherence in [Artzner et al. 1997], allow for the consequence in risk evaluation (see [Uniejewski 2004]). We can define the first order stochastic dominance in the following way:

\section{Definition (stochastic dominance of the first order)}

If variable $X$ dominates stochastically variable $Y$ it can be written

$$
X \leq Y \text { then } F_{1}(x) \leq F_{2}(y) .
$$

So the distribution function $F_{2}(y)$ dominates the distribution function $F_{1}(x)$.

This definition is not the same as the definition in the literature, but also seems to be rational as the domination may denote superiority and privileged position. We will now present the lemma concerning the monotonicity of a coherent risk measure, used for defining monotonicity in the article of Acerbi and Tasche (see [2002]), and then in the Master dissertation of Uniejewski (see [2004]). This theorem is the following:

\section{Lemma 2.1}

For variables of risk $X$ and $Y$ and the measure of risk $\rho$ the truth is the equivalence 


$$
X \leq Y \Rightarrow \rho(X) \leq \rho(Y) \Leftrightarrow(X \geq 0 \Rightarrow \rho(X) \leq 0) .
$$

We will show that this equivalence is not true, while the truth is the following opposite relation written in lemma 2.2 .

\section{Lemma 2.2}

For variables $X$ and $Y$ and the measure of risk $\rho$

$$
X \leq Y \Rightarrow \rho(X) \leq \rho(Y) \Leftrightarrow(X \geq 0 \Rightarrow \rho(X) \geq 0) .
$$

This axiom ensures that risk is detected [Artzner 1998].

To measure risk we can use volatility measures. The easiest and less accurate measure of risk is mid-range. It is a half of the difference between the biggest and the smallest value of random return for data from a particular time interval. The formula for the mid-range is the following:

$$
\sigma=0,5\left(R_{\max }-R_{\min }\right) .
$$

Another measure mentioned in the literature, but not coherent in reality, is also the median absolute deviation described by the following formula:

$$
\rho(X)=\text { Median }|X-\operatorname{Median}(X)|,
$$

where the median denotes the value in the middle in the ordered series. A similar function is the arithmetic mean of absolute deviations of possible values of random variable from the median, which in the empirical version has the following form and will be named as the arithmetic mean of the absolute deviations of values of the random variable from the median. The last measure of risk taken into account is quantile, defined as follows:

$$
P\left(R \leq R_{\alpha}\right)=\alpha
$$

where $R$ is a risk variable, $R_{\alpha}$ is a quantile, $P$ is a measure of probability and $\alpha$ is a probability value. In the calculations we will use its estimator called empirical quantile.

\section{Definition}

Let $X_{1}, \ldots X_{n}$ be the sample from the distribution with a probability distribution function $\mathrm{F}$, then the empirical probability distribution function

$$
F_{n}^{\wedge}(x): R \times \Omega \rightarrow[0,1]
$$

is defined as follows: 


$$
F_{n}^{\wedge}(x)=\frac{\bigcup_{i}\left\{i: X_{i} \leq x\right\}}{n} .
$$

$x_{p}$ is called empirical quantile of rank $p$ if

$$
F_{n}^{\wedge}\left(x_{p}\right) \leq p .
$$

Source: own definition on the basis of literature.

\section{Theorem (Gliwienka - Cantelle: The Fundamental Theorem of Statistics)}

Let $D_{n}=\sup _{-\infty<x<+\infty}\left|F_{n}(x)-F(x)\right| . X_{1}, \ldots X_{n}$ comes from the distribution with probability distribution function $F, n \rightarrow \infty$, then $D_{n} \rightarrow 0$ with the probability equals 1 .

The theorem states that the empirical distribution is convergent with the probability to the theoretical distribution. This means that in practical applications one can substitute the theoretical probability distribution function, which is often impossible to set down, by the empirical probability distribution function. We will try to prove the theoretical properties of the above functions. The property which allows us to use them in every case is coherence [Uniejewski 2004]. First we will check whether the considered functions fulfill the postulates of measure, i.e. if they are a measure of risk in the sense of the assumed definition [Trzpiot 2008].

\section{Theoretical results}

First we will show that the Expected Value and its particular case Expected Shortfall (ES), are not measures of risk in the sense of Artzner et.al. axioms, with the assumed definition of stochastic order, because the monotonicity axiom is not true for them

- monotonicity (counterexample).

Assume that $X \leq Y$, so from the definition of comparing random variables (see [Uniejewski 2004])

$$
F(X) \leq F(Y) .
$$

We define the variable $X$ as follows:

$$
\begin{gathered}
P(X \leq x) \leq P(Y \leq y) . \\
\sum_{x_{i}<x} p_{i} \leq \sum_{y_{i}<y} p_{i} .
\end{gathered}
$$

Assumptions: $x>\operatorname{VaR}, y>\operatorname{VaR}$ 


$$
\begin{gathered}
\rho(X)=\sum_{i=1}^{n} x_{i} p_{i} \geq \sum_{i=1}^{n} y_{i} p_{i}=\rho(Y) . \\
E(X / x>V a R) \geq E(Y / y>\operatorname{VaR}), \\
\rho(Y) \leq \rho(X) .
\end{gathered}
$$

- invariance:

$$
\begin{gathered}
\rho(\alpha+X)=\sum_{i=1}^{n}\left(\alpha+x_{i}\right) p_{i}=\sum_{i=1}^{n} \alpha p_{i}+\sum_{i=1}^{n} x_{i} p_{i}=\alpha \sum_{i=1}^{n} p_{i}+\sum_{i=1}^{n} x_{i} p_{i}= \\
\alpha+E(X)=\alpha+\rho(X) .
\end{gathered}
$$

The sum of the probabilities of probability distribution of a random variable from the definition of random variable equals one, but should be $\rho(X)-\alpha$

- $\quad$ positive homogeneousness, for every $\lambda \geq 0$

$$
\rho(\lambda X)=\sum_{i=1}^{n} \lambda x_{i} p_{i}=\lambda \sum_{i=1}^{n} x_{i} p_{i}=\lambda \rho(X),
$$

- $\quad$ subadditivity

$$
\rho(X+Y)=\sum_{i=1}^{n}\left(x_{i}+y_{i}\right) p_{i i}=\sum_{i=1}^{n} x_{i} p_{i}+\sum_{i=1}^{n} y_{i} p_{i}=\rho(X)+\rho(Y) .
$$

We used the distributive law for a series of numbers.

We will conduct the mathematical proofs of properties of measures of risk for cases when the random variable is continuous.

- monotonicity (counterexample)

We take $x=3 y=2 . y<x$ It means that

$$
\int_{-\infty}^{\infty} y f(y) d y<\int_{-\infty}^{\infty} x f(x) d x
$$

(from the low of monotonicity of integral).

So $E(Y)<E(X)$ so $\rho(Y)<\rho(X)$.

- Invariance

$$
\rho(X+\alpha)=\int_{-\infty}^{\infty}(x+\alpha) f(x) d x=\int_{-\infty}^{\infty} x f(x) d x+\alpha \int_{-\infty}^{\infty} f(x) d x=\rho(X)+\alpha .
$$

We used the definition of Expected Value for continuous random variable and the properties of integrals. 
- $\quad$ positive homogenousness: for every $\lambda \geq 0$

$$
\rho(\lambda X)=\int_{-\infty}^{\infty} \lambda x f(x) d x=\lambda \int_{-\infty}^{\infty} x f(x) d x=\lambda \rho(X) .
$$

A constant may be put before the integral, which follows from the properties of integral

- $\quad$ strong subadditivity

$$
\begin{gathered}
\rho(X+Y)=E(X+Y)=\int(x+y) f(x+y) d x d y=\int x f_{1}(x)+\int y f_{2}(y) d y= \\
E(X)+E(Y)=\rho(X)+\rho(Y) .
\end{gathered}
$$

Where $f_{2}(y), f_{1}(x)$ denote marginal densities. The proof follows from the properties of Expected Value. Another function of risk for a discrete random variable may be

$$
\rho(X)=\max x_{i} p_{i}
$$

This is maximum loss when taking into account probability (see [Czernik 2003]). The proofs of conditions of coherent measures of risk are presented below

- monotonicity (counterexample)

Table 1. Random distribution

\begin{tabular}{|c|c|c|c|c|}
\hline $\mathrm{Y}_{\mathrm{i}}$ & 1 & 2 & 3 & 4 \\
\hline $\mathrm{P}_{\mathrm{i}}$ & $\frac{1}{4}$ & $\frac{1}{4}$ & $\frac{1}{4}$ & $\frac{1}{4}$ \\
\hline
\end{tabular}

Source: own computations.

and the distribution of $X$ as:

Table 2. Random distribution

\begin{tabular}{|c|c|c|c|c|}
\hline $\mathrm{Xi}$ & 1 & 2 & 3 & 4 \\
\hline $\mathrm{Pi}$ & $\frac{1}{8}$ & $\frac{1}{8}$ & $\frac{1}{4}$ & $\frac{1}{2}$ \\
\hline
\end{tabular}

Source: own computations.

We see that

$$
F(x)<F(y), \text { but } \max _{i} x_{i} p_{i}=2 \text {. } \max _{i} y_{i} p_{i}=1 \text {. So } \rho(Y)<\rho(X) .
$$


- Invariance

$$
\rho(X+\alpha)=\max \left(x_{i} p_{i}+\alpha\right)=\max x_{i} p_{i}+\alpha=\rho(X)+\alpha .
$$

- Positive homogeneousness: for every $\lambda \geq 0$

$$
\rho(\lambda X)=\max \lambda x_{i} p_{i}=\lambda \max x_{i} p_{i}=\lambda \rho(X) .
$$

- Strong subadditivity

$$
\rho(X+Y)=\max \left(x_{i} p_{x_{i}}+y p_{y_{i}}\right)=\max x_{i} p_{i}+\max y_{i} p_{i}=\rho(X)+\rho(Y) .
$$

We will conduct proofs for the function of Median.

- monotonicity (counterexample).

Suppose that random variable $X$ is found in the table 3 .

Table 3. Random distribution

\begin{tabular}{|c|c|c|c|}
\hline $\mathrm{X}_{\mathrm{i}}$ & 1 & 2 & 3 \\
\hline $\mathrm{P}_{\mathrm{i}}$ & $\frac{1}{8}$ & $\frac{1}{8}$ & $\frac{3}{4}$ \\
\hline
\end{tabular}

Source: own computations.

What is more, the random variable $Y$ has probability distribution in the frames of the table below.

Table 4. Random distribution

\begin{tabular}{|c|c|c|c|}
\hline $\mathrm{Y}_{\mathrm{i}}$ & 1 & 2 & 3 \\
\hline $\mathrm{P}_{\mathrm{i}}$ & $\frac{1}{4}$ & $\frac{1}{4}$ & $\frac{1}{2}$ \\
\hline
\end{tabular}

Source: own computations.

We assume that variable $Y$ dominates over $X$ in the sense of domination of the new first order

$$
F(x) \leq F(y) .
$$

So

$$
\operatorname{Mediana}(Y) \leq \text { Mediana }(X) \text {. }
$$

And $\rho(Y) \leq \rho(X)$. 
Since the stochastic dominance makes sense only for the same space of elementary events, the median which does not depend on the probability, will be the same for both the variables compared.

- Assumption: $\lambda \geq 0$.

We number the observations from 1 to $n$ and we sort them from the least to the largest. We take into consideration only two cases

- The natural number $n$ is odd

$$
\rho(\lambda X)=\operatorname{Median}(\lambda X)=\lambda x_{\frac{n+1}{2}}=\lambda \operatorname{Median}(X)=\lambda \rho(X) .
$$

- The natural number $n$ is even

$$
\rho(\lambda X)=\operatorname{Median}(\lambda X)=\frac{\lambda x_{n}+\lambda x_{n+1}}{2}=\lambda \frac{\frac{x_{n}}{2}+x_{n+1}}{2}=\lambda \text { Median }=\lambda \rho(X) \text {. }
$$

- $\quad$ Strong subadditivity.

- The natural number $n$ is odd

$$
\begin{gathered}
\rho(X+Y)=\operatorname{Median}(X+Y)=(X+Y)_{\frac{n+1}{2}}= \\
\operatorname{Median}(X)+\operatorname{Median}(Y)=\rho(X)+\rho(Y) .
\end{gathered}
$$

- The natural number $n$ is even

$$
\begin{gathered}
\rho(X+Y)=\operatorname{Median}(X+Y)=\frac{\frac{n}{2}+\frac{n}{2}+1}{2}= \\
\operatorname{Median}(X) \frac{\frac{n}{2}+\frac{n}{2}+1}{2}+\operatorname{Median}(Y) \frac{\frac{n}{2}+\frac{n}{2}+1}{2}=\rho(X)+\rho(Y) .
\end{gathered}
$$

We will check if the other functions are coherent risk functions in the sense of the definition of the author. For this purpose we will perform mathematical proofs of the Artzner et al. properties. The first proof concerns Median Absolute Deviation.

- Monotonicity. For $X, Y \in V$. If $X \leq Y$, then $\rho(X) \leq \rho(Y)$

Assumption: $F_{1}(x) \leq F_{2}(y)$.

So for all $x$ and $y$

$$
\rho(X)=\operatorname{MEDIAN}|X-\operatorname{MEDIAN}(X)| \leq \operatorname{MEDIAN}|Y-\operatorname{MEDIAN}(Y)|=\rho(Y)
$$

So $\rho(Y) \leq \rho(X)$. 


\section{MONOTONICITY DOESN'T EXIST}

- Invariance

Counterexample

$$
\begin{gathered}
X=\{1,2,3,4\} P\left(X=x_{i}\right)=1 / 4 \\
\rho(X+1)=\operatorname{Median}|X+1-\operatorname{Median}(X+1)|=1, \\
\rho(X)-1=\operatorname{Median}|X-\operatorname{Median}(X)|-1=0 .
\end{gathered}
$$

- Strong subadditivity for cases of series of equal length

$$
\begin{gathered}
\rho(X+Y)=\operatorname{Median}|X+Y-\operatorname{Median}(X+Y)|= \\
\text { Median }|X+Y-\operatorname{Median}(X)-\operatorname{Median}(Y)|= \\
\text { Median }(|X-\operatorname{Median}(X)|+|Y-\operatorname{Median}(Y)|)=
\end{gathered}
$$

$\operatorname{Median}|X-\operatorname{Median}(X)|+\operatorname{Median}|Y-\operatorname{Median}(Y)|=\rho(X)+\rho(Y)$.

- Positive Homogeneousness

$$
\begin{gathered}
\rho(\lambda X)=\text { Median }|\lambda X-\operatorname{Median}(\lambda X)|=\operatorname{Median}|\lambda X-\lambda \operatorname{Median}(X)| \\
|\lambda| \text { Median }|X-\operatorname{Median}(X)| \geq \lambda \rho(X) .
\end{gathered}
$$

\section{LACK OF HOMOGENOUSNESS}

The next proofs will be conducted for Mid-Range

- Monotonicity for

$$
X, Y \in V \text { for } X, Y \in V \text {, If } X \leq Y \text { then } \rho(X) \leq \rho(Y) .
$$

Counterexample

Suppose that random variable $X$ is found in the following table.

Table 5. Random distribution

\begin{tabular}{|c|c|c|c|}
\hline $\mathrm{x}_{\mathrm{i}}$ & 1 & 2 & 3 \\
\hline $\mathrm{p}_{\mathrm{i}}$ & $\frac{1}{4}$ & $\frac{1}{4}$ & $\frac{1}{2}$ \\
\hline
\end{tabular}

Source: own computations. 
We notice that variable $Y$ dominates over $X$ in the sense of domination of the first order

$$
\begin{gathered}
F(x) \leq F(y), \\
\rho(X)=0.5(3-1)=1>0.5=0.5(2-1)=\rho(Y) .
\end{gathered}
$$

\section{LACK OF MONOTONICITY}

- Invariance

$$
\begin{gathered}
\rho(X+\alpha)=0.5\left((X+\alpha)_{\max }-(\mathrm{X}+\alpha)_{\min }\right)=0.5\left(X_{\max }-X_{\min }\right) \\
0.5\left(X_{\max }-X_{\min }\right) \geq 0.5\left(X_{\max }-X_{\min }\right)-\alpha .
\end{gathered}
$$

\section{LACK OF INVARIANCE}

- Subadditivity

$$
\begin{gathered}
\rho(X+Y)=0.5\left((X+Y)_{\max }-(X+Y)_{\min }\right)=0.5\left(X_{\max }+Y_{\max }-X_{\min }-Y_{\min }\right) \\
0.5\left(X_{\max }-X_{\min }\right)+0.5\left(Y_{\max }-Y_{\min }\right)=\rho(X)+\rho(Y) .
\end{gathered}
$$

\section{SUBADDITIVITY EXISTS}

- Positive Homogeneousness

$$
\rho(\lambda X)=0.5\left((\lambda X)_{\max }-(\lambda X)_{\min }\right)=\lambda 0.5\left((X)_{\max }-(X)_{\min }\right)=\lambda \rho(X) .
$$

\section{HOMOGENOUSNESS EXISTS}

The proposed measure was also Quantile. For this function the mathematical proofs of the basic properties are the following:

- Monotonicity Counterexample

$$
\begin{gathered}
X=\{-1\}, Y=\{3\}, \\
P\left(X=x_{1}\right)=1, \\
P\left(Y=y_{1}\right)=1,
\end{gathered}
$$




$$
\rho(X)=P(x \leq 1) \geq P(y \leq 1)=\rho(Y) .
$$

- Invariance Counterexample

$$
\begin{gathered}
X=\{2,3\}, \quad R_{\alpha}=2 P\left(x=x_{1}\right)=0.5, \quad a=4, \\
0.5=P(x \leq 2)=P(x \leq 6-4) \neq P(x \leq 6)-4=1-4=-3 .
\end{gathered}
$$

\section{LACK OF INVARIANCE}

- Subadditivity

$$
\begin{gathered}
P\left(X+Y \leq R_{\alpha}\right)=\sum_{x+y \leq R_{\alpha}} P(X=x) P(Y=y) \leq \sum_{x+y \leq R_{\alpha}} P(X \leq x) P(Y \leq y) \leq \\
\frac{\sum_{x+y \leq R_{\alpha}}\left(P(X \leq x)^{2}+P(Y \leq y)^{2}\right)}{2} \leq \sum_{x+y \leq R_{\alpha}}(P(X \leq x)+P(Y \leq y)) \\
\leq P\left(X \leq R_{\alpha}\right)+P\left(Y \leq R_{\alpha}\right) .
\end{gathered}
$$

\section{SUBADDITIVITY EXISTS}

- Positive Homogeneousness.

Counterexample

$$
\begin{aligned}
& \lambda=\frac{1}{2}, X=\{3\}, P\left(X=x_{i}\right)=1, R_{\alpha}=3, \\
& 1=P(X=3)=P(1 \leq 3) \neq \frac{1}{3} P(3 \leq 3)=\frac{1}{3} .
\end{aligned}
$$

\section{LACK OF HOMOGENOUSNESS}

At this stage of the survey we will research the properties of "Arithmetic Mean of Absolute Deviations from Median”.

- Monotonicity.

\section{Counterexample}

Suppose that random variable $X$ is found in the following table 
Table 6. Random distribution

\begin{tabular}{|c|c|c|c|}
\hline$x_{i}$ & 1 & 2 & 3 \\
\hline$p_{i}$ & $\frac{1}{8}$ & $\frac{1}{8}$ & $\frac{3}{4}$ \\
\hline
\end{tabular}

Source: own computations.

What is more the random variable $Y$ has probability distribution in the frames of the table below.

Table 7. Random distribution

\begin{tabular}{|c|c|c|c|}
\hline$y_{i}$ & 1 & 2 & 3 \\
\hline$p_{i}$ & $\frac{1}{4}$ & $\frac{1}{4}$ & $\frac{1}{2}$ \\
\hline
\end{tabular}

Source: own computations.

We notice that variable $Y$ dominates over $X$ in the sense of domination of the first order.

$$
\begin{gathered}
F(x) \leq F(y) \\
\rho(Y)=\frac{1}{3} \sum_{i=1}^{3}\left|y_{i}-\mu_{y}\right|=\frac{1}{3}, \quad \rho(X)=\frac{1}{3} \sum_{i=1}^{3}\left|x_{i}-\mu_{x}\right|=\frac{2}{3}, \\
\text { so } \rho(\mathrm{Y})<\rho(\mathrm{X}) .
\end{gathered}
$$

\section{LACK OF MONOTONICITY}

- Invariance.

Counterexample

$$
\begin{gathered}
X=\{1,2,3,4\} \quad P\left(X=x_{i}\right)=\frac{1}{4}, \\
\rho(X+1)=\frac{1}{4} \sum_{i=1}^{4}\left|x_{i}+1-\operatorname{Median}(X+1)\right|=1, \\
\rho(X)-1=\frac{1}{4} \sum_{i=1}^{4}\left|x_{i}-\operatorname{Median}(X)\right|-1=0 .
\end{gathered}
$$




\section{LACK OF INVARIANCE}

$$
\begin{gathered}
\rho(X+Y)=\frac{1}{4} \sum_{i=1}^{4}\left|x_{i}+y_{i}-\operatorname{Median}(X+Y)\right| \\
\leq \frac{1}{4} \sum_{i=1}^{4}\left|x_{i}-\operatorname{Median}(X)\right|+\frac{1}{4} \sum_{i=1}^{4}\left|y_{i}-\operatorname{Median}(Y)\right|=\rho(X)+\rho(Y) .
\end{gathered}
$$

\section{SUBADDITIVITY EXIS}

- Homogeneousness.

$$
\begin{gathered}
\rho(\lambda X)=\frac{1}{4} \sum_{i=1}^{4}\left|\lambda x_{i}-\operatorname{Median}(\lambda X)\right|= \\
\frac{1}{4}|\lambda| \sum_{i=1}^{4}\left|x_{i}-\operatorname{Median}(X)\right| \geq \frac{1}{4} \lambda \sum_{i=1}^{4}|X-\operatorname{Median}(X)|
\end{gathered}
$$

\section{LACK OF HOMOGENOUSNESS}

We will prove the opposite lemma 2.2.

$(\Leftarrow)$

The author assumes that $\rho(X) \leq \rho(Y)$ for $X \leq Y$ and $X \geq 0$. From the positive homogeneousness property: $\rho(0)=\rho(0 \cdot X)=0 \cdot \rho(0)=0$.

So $\rho(X) \geq 0$.

$(\Rightarrow)$

The author assumes that $\rho(X) \geq 0$ for $X \geq 0$ and $X \leq Y$.

Using the monotonicity axiom the author receive:

$$
\rho(X) \leq \rho(Y)
$$

\section{Conclusions}

1. With the opposite definition of stochastic order, the classical Expected Value and its special case Conditional Expected Value - Expected Shortfall, are not coherent measures of risk because they do not fulfill one of the axioms of Artzner both in discrete and in continuous cases.

2. The function - Maximum Loss for losses weighted with probability - is not a coherent measure of risk in the sense of its definition in this paper.

3. Median is not a coherent measure of risk in a sense of new the definition. 
4. The other functions of risk considered in this article often did not fulfill the conditions of measure which is new in this article and what is known also as the coherence properties. Some axioms of Artzner [Artzner et al. 1997] fulfill only the midrange and arithmetic mean of "absolute deviations from median"

5. We contradicted the lemma of monotonicity (lemma 2.1). This lemma was used in the proofs of monotonicity of Expected Shortfall in the literature. Then we proved the opposite theorem.

The functions researched in this article are in the sense of axioms of Artzner et al. not good measures of risk when we change the definition of stochastic order. What is more, the opposite order defining the monotonicity of risk measures in relation to the literature is true.

\section{Bibliography}

Acerbi C., 2002, Spectral Measures of Risk: a Coherent Representation of Sub- jective Risk Aversion, Abaxbank, Corso Monforte 34, 20122 Milano (Italy), DOI: 10.1016/S0378-4266(02)00281-9.

Acerbi C., Tasche D., 2002, On the coherence of expected shortfall, Journal of Banking \& Finance, Volume 26, Issue 7, July, pp. 1487-1503.

Artzner Ph., Delbaen F., Eber J.M., Heath D., 1997, Thinking coherently, Risk, 10, November, 68-71.1997, DOI: $10.1201 / \mathrm{b} 15055-1$.

Artzner Ph., Delbaen F., Eber J.M., Heath D., 1998, Coherent Measures of Risk https://people. math.ethz.ch/ delbaen/ftp/preprints/CoherentMFdf.

Buszkowska E., 2015, O fundamentach pomiaru ryzyka, Zeszyty Naukowe: Finanse, Rynki Finansowe Ubezpieczenia, Szczecin.

Czernik T., 2003, Maksymalna strata jako miara ryzyka, Prace Naukowe Akademii Ekonomicznej w Katowicach.

Ferguson Ch.H., 2010, Inside Job, Documentary film, USA.

Jajuga K., 2007, Zarządzanie ryzykiem, Wydawnictwo Naukowe PWN SA, Warszawa.

Staniec I., Zawiła-Niedźwiedzki J., 2008, Zarządzanie ryzykiem operacyjnym, Warszawa.

Trzpiot G., 2008, O wybranych własnościach miar ryzyka, Badania Operacyjne i Decyzje.

Uniejewski P., 2004, Koherentne miary ryzyka, Wrocław. 